\title{
Promenade Locale: Walking Practice as Performance
}

\section{Cover Page Footnote}

Georgia Snowball was supported by an Australian Government Research Training Program (RTP) Stipend and RTP Fee-Offset Scholarship through Federation University Australia. Acknowledgements are also due to the Mount Alexander Shire Council Small Grants Program, plus all participants, in particular Amy Chapman and Sally Davis. 
This article outlines the process of creating a "mis-guided tour" for performance that is site-specific and participatory. It develops and narrates concepts of audience encounters with place through the practice-led-research performances of Promenade Locale. The Promenade Locale series was performed over three consecutive years from 2014-2016, as part of the Castlemaine Fringe Festival in Central Victoria, Australia. Emerging "walking practice" has been both critiqued and activated through a performance context in the UK by many, including Dee Heddon and Cathy Turner, ${ }^{2}$ Baz Kershaw, Jess Allen and Mike Pearson. ${ }^{3}$ Members of UK Company, Wrights \& Sites, developed the concept of the "mis-guided tour" 4 to "employ disrupted walking strategies as tools for playful debate, collaboration, intervention and spatial meaning-making." ${ }^{5}$ Walking continues to be a diverse modality for differing performance events, practice-led-research, and audience/performer experiments. These take place both nationally and internationally, and across performing arts disciplines.

The activity of walking is currently popular in Australia within the broader field of performance studies; this paper investigates a local and regional discourse around walking as a performative event. Australian walker and artist Perdita Phillips writes, "I believe walking continues to offer a tactical space because of the way that it combines place, motion, the body and others together in an unruly mix." ${ }^{" 6}$ In what follows, I focus on the implications of what Phillips' "unruly mix" may reveal, while walking in Promenade Locale.

To provide a short background to the field, I include examples from other artists using walking as a form of expression, communication and performance making. Mark Minchinton and Domenic de Clario's long-distance walks across Western Australia exemplify a solitary and extended practice that took place over weeks and months. ${ }^{7}$ More recently De Clario followed the Murray River in Victoria from source to mouth in Walking Slowly Downhill (2015). ${ }^{8}$ In Victoria, the walking tour, mobility, ${ }^{9}$ and movement of an audience, in general, have been popular modes in performance events. For example, the Environmental Performance Authority (EPA) performed the Smellbourne Toilet Tour (2016), as part of their M47 performance series in Melbourne. ${ }^{10}$ PSi \#22 Melbourne: Performance Climates curated several tours and walks around the Melbourne CBD and surrounds for Performing Mobilities, 
in a work known as "Passages: Mobile Performances." ${ }^{11}$ Locally, in Central Victoria, Punctum Inc. has also hosted numerous performances involving walking tours, ${ }^{12}$ walking experiments, ${ }^{13}$ and historical and cultural walking practices and events. ${ }^{14} \mathrm{My}$ contention is that this surge of enthusiasm for this simple and straightforward activity in the performing arts, particularly in Australia, is associated with the potential for walking to reach into and connect with varied communities of all backgrounds in diverse locations. Although there is a distinction between the long-distance walks of de Clario and Minchinton and the humorous short tours of the EPA, in both instances the theme of embodied participation in place through walking exemplifies the experience of audience and performer moving through and between different encounters. Observing sensorial feedback through walking emphasizes being in and moving through a different locale, or being in and moving through a locale differently.

In this article, I discuss methods of the performance-making process, and for documenting real-time feedback from the audience. The performances discussed sought to guide the participants through the streets of Castlemaine, engaging with a sensorial and active relationship with the everyday while en route. Promenade Locale works to distract audience participants from an ordinary experience of their own town while offering up new imaginings experienced through encounters with both tactile tasks and story. The score of the performative event was created out of vignettes, involving physical movement and short narratives, pointing out and responding to "mythogeographic" qualities of place. I consider how the performance series of Promenade Locale became an example of Michel de Certeau's spatial practice of enunciation, ${ }^{15}$ through and with the spectator-participants. I also reveal the processes and tactics behind the adapted tropes of a "mis-guided tour." 16

A metaphorical narrative of both real and imagined stories, events and geographic features of Castlemaine surround the practice-as-research event. Spoken by the author, the textual score invited opportunities for participants to take part in a unique experience of place. The initial written documentation of the performanceincluding photographs and feedback questionnaires - served as the basis for analyzing the outcomes of the performance work. Preparations for viewing the video work at a later date have also helped to form research material to critique. It is through this range of experience, documentation, and research data that I derive evidence to discuss issues of spectator participation and relationship to place. 


\section{The Scene}

Michel de Certeau's concept of walking as a spatial practice and Erika Fischer-Lichte's writings around spectatorship inform the underlying themes of the work: to potentially alter audience perception of place, "to activate the spectator"17 through active participation, framed by the physical performance event of walking. The performance was designed in the mode of participatory practice, aiming to contribute to Erika Fischer-Lichte's concept of "transformative aesthetics" for spectators in live performance.

De Certeau's spatial practice takes into account a multidimensional view of space that is constantly changing and being changed by its inhabitants. Included in this view, for example, are the tracks and traces of people, animals, weather, and traffic. Architectural vantage points, maps, and the contrast between past and present are also observed within a space. De Certeau reads the hidden everyday comings and goings inside different spaces, making poetic connections and relationships with and for new space and place. ${ }^{18}$ Fischer-Lichte looks at spectator-participant process, in performance viewing, as being an active role that "enables transformations." 19 Both theorize the role of active encounters with different spaces as being key to the creation of new ways of sensing and participation. The different spaces and places of experiencing and meaning making created by the performance work Promenade Locale reflects and builds on both de Certau's concept of spatial practice and Fischer Lichte's active spectator discussion.

Participant/performer relations were enabled through the "mis-guided tourguide" role in which the performer (and author) also participated, to some degree, as a spectator. As the performer/participant, I directed particular attention toward developing a tour that was both "performance-like"20 and performative. Barbara Bolt explains the importance of the performative in artistic practice-led-research: "performativity has invited new ways of analysis, modes that focus on process, participation, events, expressive actions and experience." 21 These artistic tropes framed the process to inspire participant involvement through the performative events. Included below, are some of the most fruitful and poignant interactions that demonstrate an embodiment of a new experience of time and space through the activity of the "mis-guided tour." 
The "mis-guided tour" 22 is essentially an anti-consumer and non-touristic concept of both being in, and exploring, urban areas, with roots in a Situationist rationale. Phil Smith of Wrights \& Sites explains the approach:

Walking — wandering. Not buying, window shopping or taking part in leisure activities - but just letting the flows and currents and rhythms of the city pull and draw them. The situationists called this 'dérive' or 'drift': they hypersensitized themselves to the city's shapes, symbols and encounters; letting its atmospheres be their guides. ${ }^{23}$

Promenade Locale is also a contemporary response to Guy Debord's dérives. ${ }^{24}$ Debord notes: "Dérives involve playful-constructive behaviour and awareness of psychogeographical effects, and are thus quite different from the classic notions of a journey or stroll." ${ }^{25}$ Fun, humor, playfulness, and a hint of the carnivalesque created an experiential opening amongst the participant-spectators and the places they moved through.

Phenomenologist and philosopher of place Edward Casey argues, "the enactive vehicle of being-in-place is the body." ${ }^{26}$ In a more specific reference to the embodied, performative practice of walking, Michel de Certeau affirms, "in the framework of enunciation, the walker constitutes, in relation to his position, both a near and a far, a here and a there." ${ }^{27}$ Conversely, Mike Pearson contends that performance-making may actually be "place-making." 28 In the instance of Promenade Locale, the walking tour becomes "place-making" through the actions and activities of the group. Pearson goes on to say that performance, "at undifferentiated or indistinct locales within a landscape... might bring together heterogeneous elements in a moment of absorption, in intensification of affect." 29 The rich resources and multilayered aspects of a particular place enhance the significance of performing in, or walking through, a given site. These intersections of theory are highlighted in Promenade Locale by the merging roles of the performer/participant/spectator through the activity of walking the streets of Castlemaine. Following Fischer-Lichte, in her claim that a performance may be added to or even created from the actions of the participants, ${ }^{30}$ the aim of Promenade Locale was to investigate how walking has the potential to activate and transform place and one's experience of it.

Walking, once framed in a performative context, holds multiple capacities for change in relation to both participants and the places that are walked through. Aside from the ubiquitous nature of walking, the slow action confronts the busyness of modern life. Phil Smith clarifies the important regularity of walking, as a device for a 
mythogeographic tour, noting that, "the simple ambulatory exploration always remains as the primary and underpinning tactic." ${ }^{31}$ Slowing the body down and taking notice of where one is situated in time and space has wider implications for both the group and individual. De Certeau claims, "to practice space is thus to repeat the joyful and silent experience of childhood; it is, in a place, to be other and to move toward the other (italics in the original)." 32 One participant from Promenade Locale \#3 observed, "I think of my children's experience of place and the importance of slowing down. It is lovely to again let the "space be in me.",33

\section{The Streets of Town}

In researching the regional township of Castlemaine for the project, I collected stories of the Gold Rush era from the Castlemaine Information Centre, the Historical Society, and from speaking to people on the street. I studied historical facts and observed architectural features, street names, and local geography. I spent time looking at the people coming and going in the central shopping area, exchanging words, glances or meeting. The concept of mythogeography allows and makes space for the overlapping of factual information and new imaginings of place. Discovered while walking with the method in mind, it becomes a blend of geographical possibilities (taking a new path over instead of around), meanings (street signs direct traffic as well as walkers), and story (how spaces have changed function over time). The diversity of possibility, meaning, and story of place offered through mythogeography served as a basis for the method of inquiry and informed the structure and content of the "mis-guided tour." Smith explains, "Mythogeography is a hybrid of ideas, tactics and strategies. It embraces both respectable (academic, scientific, culturally validated) and non-respectable (Fortean, antiquarian, mystical, fictional) knowledges." ${ }^{34}$ Appling the concept of mythogeography to the streets and open spaces of Castlemaine, the small town became more complex, layered with new interpretations of a familiar space.

Seeking information from Castlemaine's local historical society, I was troubled to find a shortage of records or information on the Indigenous people of the area. I approached Uncle Rick Nelson, local Dja Dja Wurrung elder, hoping for some insights into the Indigenous story of Castlemaine. Although I had some monetary funds to offer in exchange, I questioned my motivations as a white woman wanting specific information to further my project. Initially, Uncle Rick seemed keen to 
contribute. After several failed attempts to meet and talk, however, I realized I was trying to fulfill personal expectations to add to the tour, and that it was not reasonable to ask this of Uncle Rick. I decided instead to invite him along to the tour, although unfortunately, he was unable to attend. As the narrator, I paid appropriate respect to the Aboriginal Elders during the tour: referring to the past, present and future Indigenous custodianship of the land.

With the concept of the "mis-guided tour" as the key focus, I could trust in any direction or detour the tour might take, and was actually looking forward to diversions and disruptions. These, of course, would only be possible if a space were created for the participants to feel comfortable as individuals, as well as taking opportunities to jostle them a little out of their comfort zones.

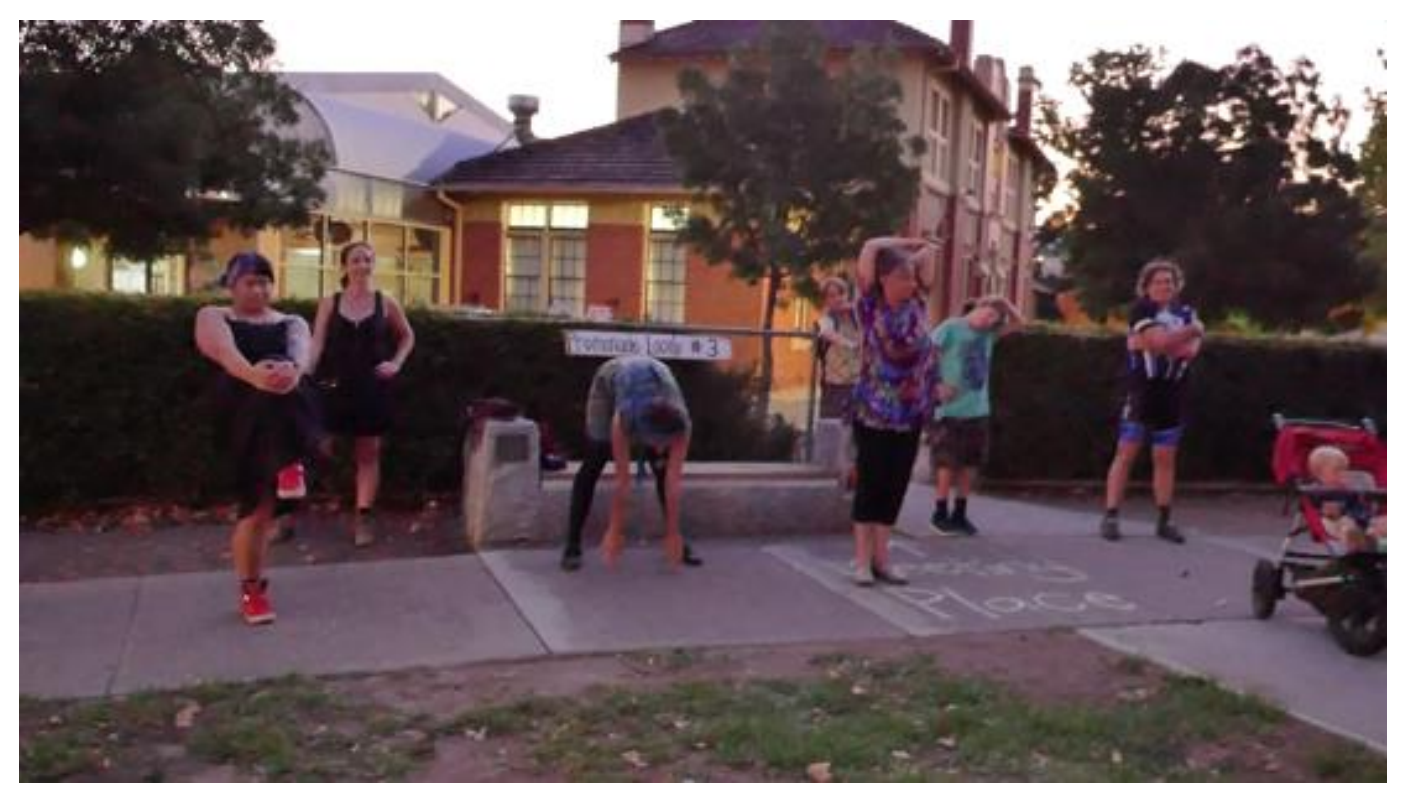

Warm- up Stretch, video still by Lisa Mills, Castlemaine 2016.

\section{The Tour}

Promenade Locale \#3 took place in autumn, in the early evening just on nightfall, and was illuminated by streetlight. The loosely designed score encouraged participant interaction and involvement, working to optimize participant's experiences in re-encountering their own everyday place. The tour worked from what was visibly obvious and overlaid it with a deeper method of observing, engaging and being in the streets of town. Audience members were given tasks and directions during the performance and then invited to consider contributing written feedback at the conclusion of the tour. 
In welcoming the group to the tour, Ms Guide (the author) formally acknowledged that the land in which we were standing on belonged to the First Peoples of Australia, the Dja Dja Wurrung. She openly thanked them for having us on their country. ${ }^{35} \mathrm{Ms}$ Guide announced her role and that of her colleague, Ms Information, in being "potential" guides for the evening. In a similar vein, at the introduction to their Water Walk (2010) tour, Phil Smith and Simon Persighetti "announced in detail all the guide-like actions we would not be performing and all the guide-like information we would not be sharing." ${ }^{36}$ Ms Guide invited the audience to interject wherever possible and to simply be themselves.

In the fading evening light, Ms Guide engaged in familiar activities, in which the group could participate, as a method of generating a sense of ease and playfulness. Laughs rose up from the group when Ms Guide initiated the beginning of the tour by swinging her arms and doing some deep squats on the pavement outside the supermarket. Others joined in, the group becoming quickly aware of the physical potentials of both the individual and the whole. The "warm-up stretch" (a performative strategy) for tours \#2 and \#3 was met with surprised giggles and looks of confusion among participants. I sensed that the mythogeographic tactics were at play. Through the tactile provocations of, for example, the blindfold walk and the many suggested instructions of, for instance, "take your partner for a trolley ride" that were announced through out the tour, the participants were able to open up to the experiences the town might provide. The members of the group didn't necessarily know each other, but it became apparent from the outset that each task acted as a release from uncertainty into activity. The threshold between performer and spectator now seemed to operate in a new temporary "liminal" atmosphere. ${ }^{37}$ As we set out, Ms Guide voiced the invitation to participants to hold hands with the person nearest to them as we all crossed the road. This invitation was carried through the whole tour series and was highly effective in creating group cohesion and an air of possibility by promoting human touch, responsibility, and trust. The ostensibly timid woman whose hand I was holding called out loudly to the rest of the group, "look left, look right, look left again, now cross."

To simply do was an ongoing provocation throughout the event and the element of surprise was definitely a useful method over the duration of the performances. Ms Guide next set the imaginary task of walking through an underground tunnel in the dark. Ms Information produced strips of black material for 
blindfolds and began putting them on the spectator-participants. We assumed people would go along with the invitations offered, without giving them too much time to decide or the option to decline. In a sense, participants had to either surrender to the directions or become just observers. Of course, we didn't mind if the participants didn't particularly want to walk up the street blindfolded, holding a stranger's hand and being encouraged to "scurry." Nevertheless, almost everyone on both nights was compliant with all the tasks. I sensed a certain trust had developed during the opening introductions (revealed in people's willingness to go along with the offers), while an uncompromising yet arbitrary tone had been set. Ms Guide proceeded with a short story that took place in a public bar where the Subway stands today. The story was picked up during conversations, as I searched for material, through everyday interactions with people on the street. ${ }^{38}$

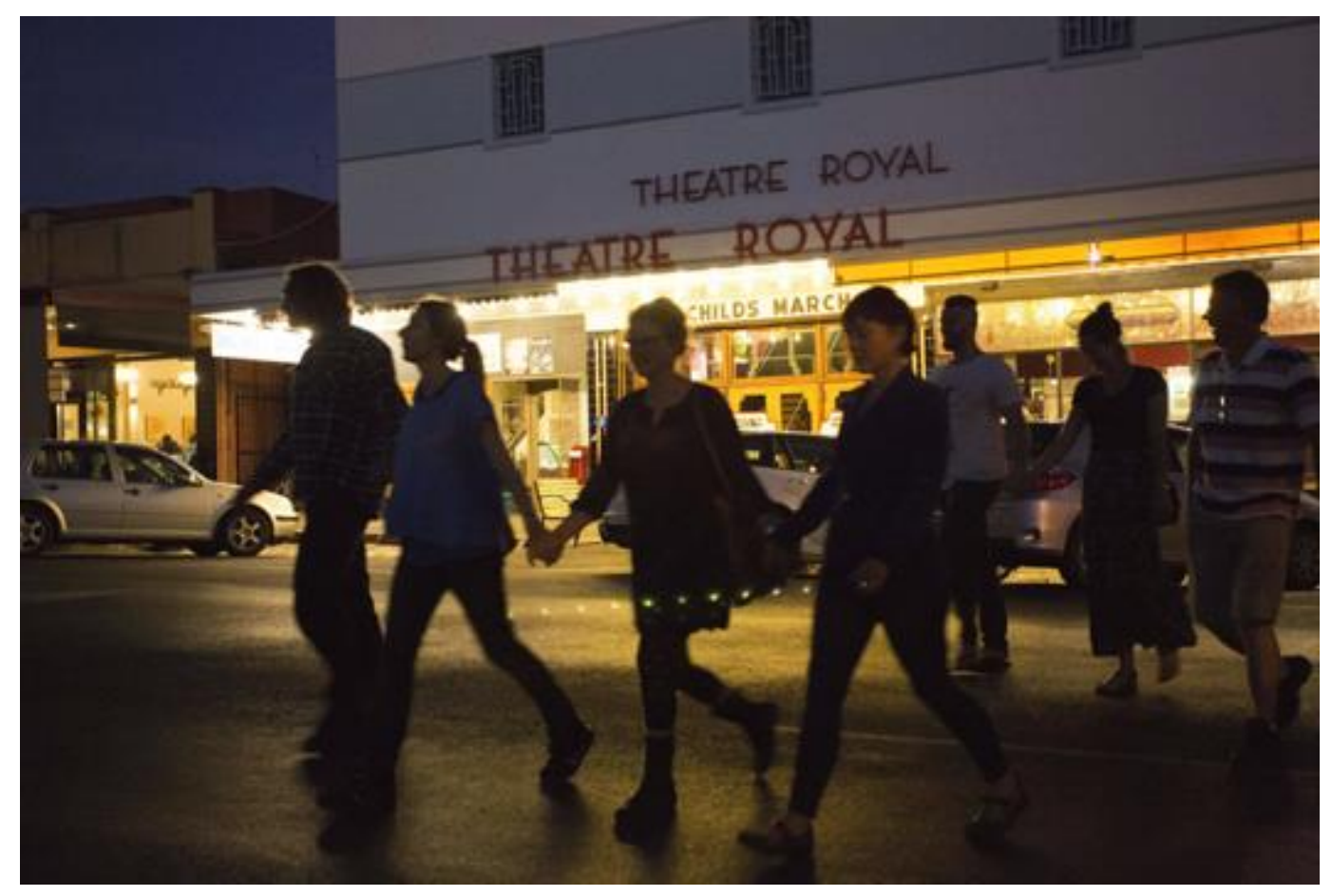

Crossing, Photo by Leonie Van Eyk, Castlemaine, 2016.

Through the spoken text, I had loosely appropriated local, albeit historical, knowledge and transferred it into an active participation for creating new knowledge. This unfolded between both people and place, allowing individual imaginations to encounter and interact with the information. Blindfolded, participants laughed and clutched each other, while "feeling" their way along the street. One person explained, "it was great to explore different modes of movement. The blindfold scurrying was 
the most difficult." ${ }^{39}$ The habitual movement of walking down the street, and the expectations of a performance to "entertain" entered another state, wherein participants tempered their own levels of excitement or intrigue by following the unknown trajectory of the tour.

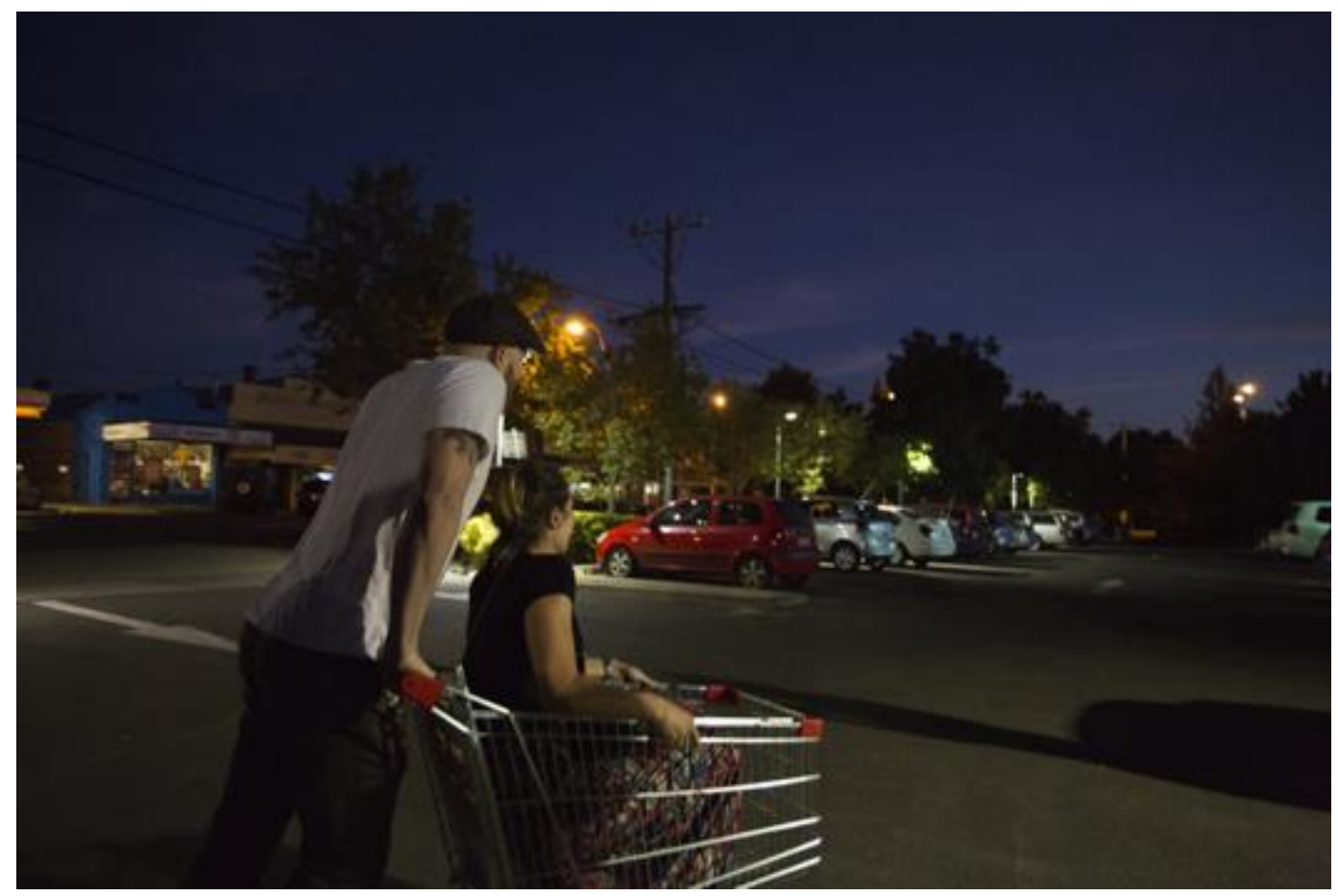

Trolley Ride, Photo by Leonie Van Eyk, Castlemaine, 2016.

Discarding the blindfolds, we once more held hands to cross the road over to the old school-yard playground, now the supermarket car park. Ms Guide invited participants to traverse the playground, escorting each other in supermarket shopping trolleys. Time was of the essence here, and I sensed the others understood this, as Ms Information came running out of the supermarket, a train of trolleys in front of her. We had spent some time over the previous week talking to "Kevin" and his coworkers at the supermarket to make sure the trolleys would be available, but he had ultimately forgotten. Group members joined in partnership with the nearest person to hurtle across the short distance of the car park, as individuals yelped with pleasure and threw their arms up in the air. Commenting on the boundaries breached and new spaces created for and with an audience, Fischer-Lichte remarks: "spectating takes place as a liminal situation. It is separated from the concerns of everyday life and opens up the possibility of aesthetic play. ${ }^{40}$ Humour played a vital role in Promenade Locale, through creating openings for people to participate in doing things they 
wouldn't normally do in usual or unusual places. This playfulness or togetherness had the effect of releasing group members from the construct of appropriate public behavior, opening up to the possibility of different ways of seeing and interacting across time and space. The "trolley ride" was an act of reclaiming space, in both a performative and "performance like" context. As one participant explained:

From my perspective, it was a wonderful way to explore the old town at night, it had a hint of brazen youthfulness, hanging out in a gang, feeling lawless. Seeing the town in a new way, discovering details of spaces that will change my view of Castlemaine forever. ${ }^{41}$

Promenade Locale became an endeavor of togetherness that harnessed the transformations inherent in play and risk-taking, to potentially experience a deeper connection with the everyday places of Castlemaine.

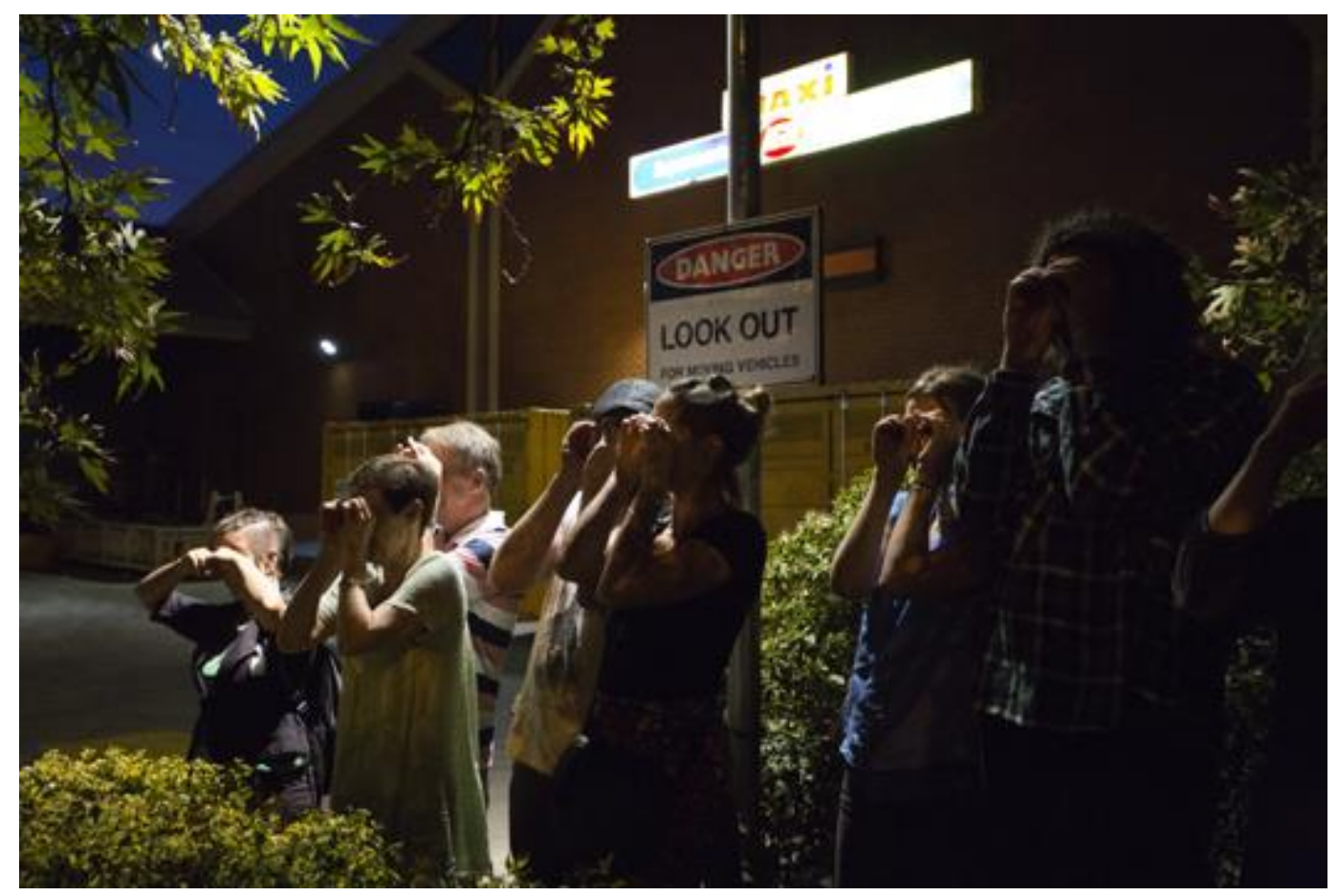

The Look Out, Photo by Leonie Van Eyk, Castlemaine, 2016.

The tour rounded the imaginary banks of Forest Creek, now Forest Street, opposite the town's sporting oval. Ms Guide funneled the audience into the "Look Out." Gathered together closely under the sign, we held our hands up to our eyes as if we had binoculars and looked "out over the gold mining boom wasteland now called Western Reserve," 42 while listening to an audio track from an unrelated cricket match. Here the juxtaposing of sound layers and vision, combined with the group's public visibility, created potentially new experiences for the observer and the observed, 
regarding what was "real" or imagined. Being seen to be doing something unusual or out of place in a small country town pushes at the boundaries of normal, accepted behavior, and has the potential to challenge local attitudes.

Storytelling, as combined with the activity of walking in Promenade Locale, became an example of Michel de Certeau's use of "demonstratives," whereby the method and aesthetics of the live performance reveal a layering of spatiotemporal relations. De Certeau explains that:

Demonstratives indicate the invisible identities of the visible: it is the very definition of a place, in fact, that it is composed by these series of displacements and effects among the fragmented strata that form it and that it plays on these moving layers. ${ }^{43}$

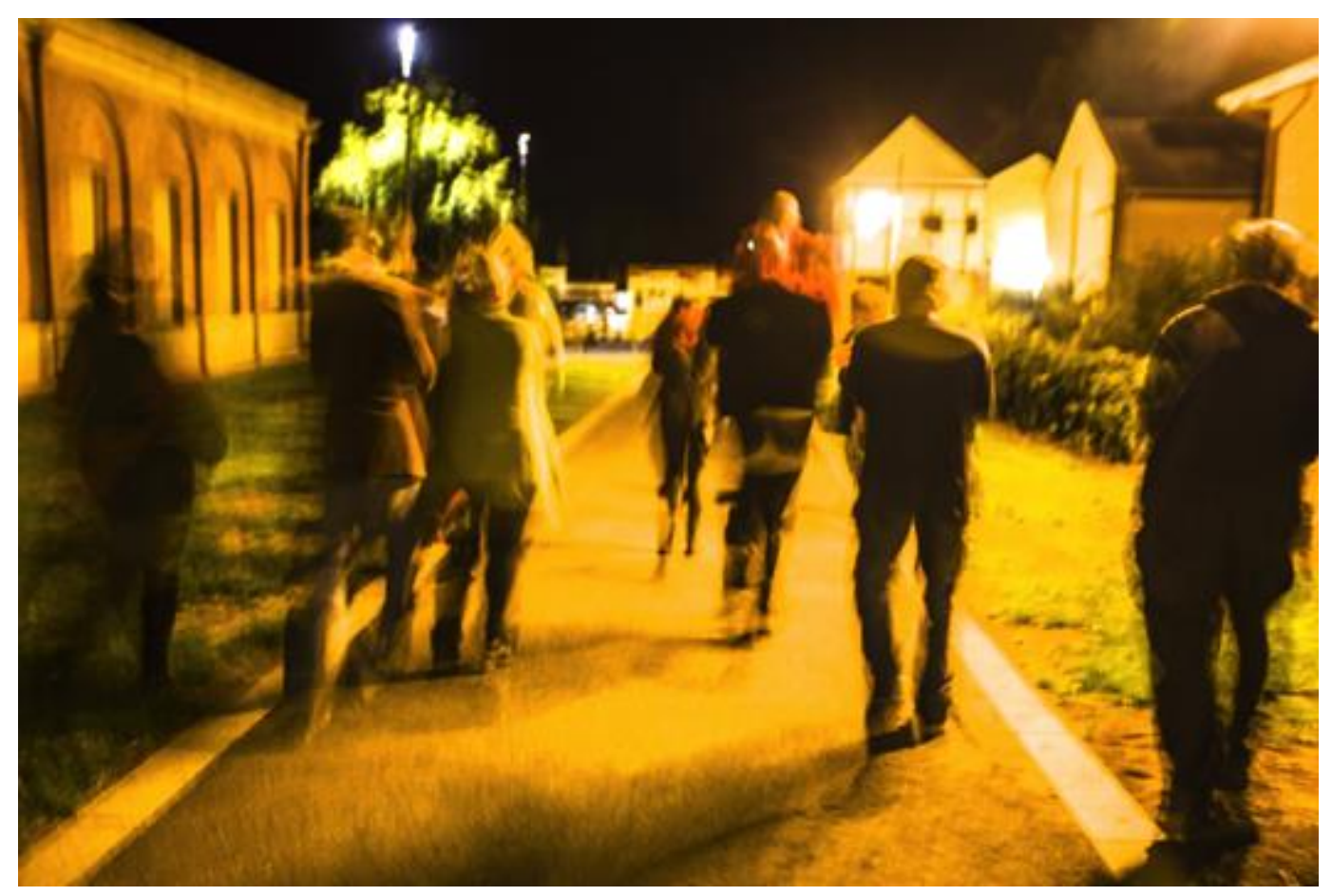

Galloping, Photo by Leonie Van Eyk, Castlemaine, 2015.

In the supermarket car park, I gave a brief historical account of the horse stables, which had once stood there. Hollowed out coconut shells were passed around and using these, the group were invited to gallop their "horses" through the old stables where the car park now stands. An intermediate confusion was quickly taken over by the acceptance of the offer "to gallop like a horse" and we took off as a group, clattering through the night sky. 
After handing our metaphorical horse hooves back to Ms Information, the group stood under the statue of Demeter on the top the Old Market Building. The section of Promenade Locale that followed continues to acknowledge Fischer-Lichte when she asserts that activity is the key to creating new experiences of interaction and encounter for spectator-participants. ${ }^{44}$ Next on the tour, Ms Information and I had piled up a collection of different-sized rocks and placed them on the steps of the Old Market Building. Members of the group were asked to pick one out and carry it with them. We then headed down to Victory Park in the middle of town. Ms Guide explained that historically horses were made to gallop up the hill ahead while heavily laden. The horse with the fastest time was sold for the highest price. ${ }^{45}$ Behind the group, Ms Information expertly cracked a long leather whip while Ms Guide encouraged the others to make good time. The physical weight of carrying the rocks merged with an extract of historical knowledge. The sound of a leather stockwhip, heightened the senses of participants as they ran. Physical activity was thus imprinted in the body, to be potentially drawn on later as memory.

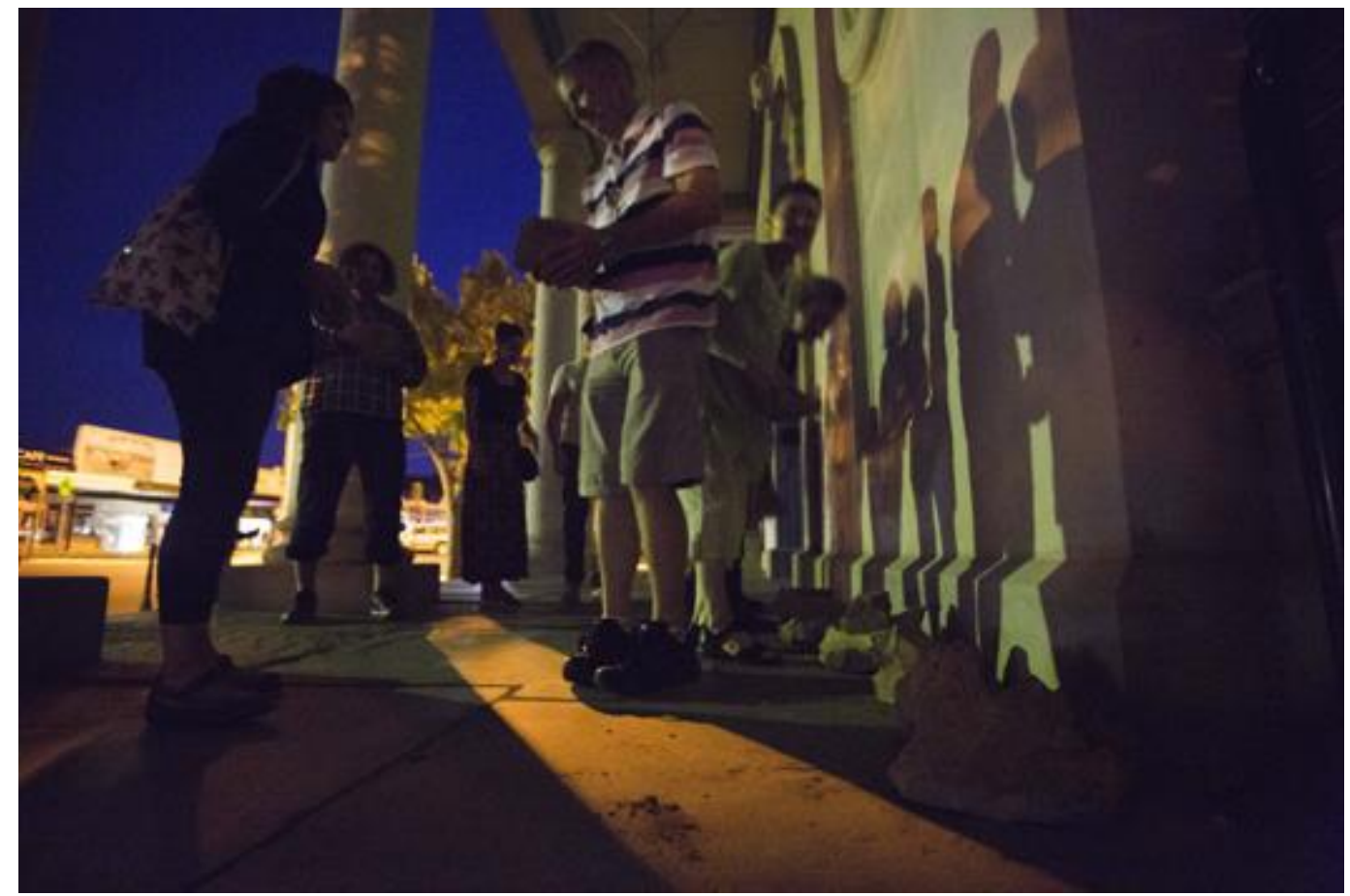

Carrying Rocks, Photo by Leonie Van Eyk, Castlemaine, 2016. 
Once inside the park, we placed our rocks on the ground. As we approached the grass in front of the children's play equipment, Ms Guide invited the group to crawl along the ground on all fours and to smell the grass, thus altering our habitual upright position. This request was met with some trepidation as both groups experienced differing measures of discomfort and mirth, negotiating clothes and bodies. "Energetic and intriguing and participatory," 46 was a description of the experience offered by one participant.

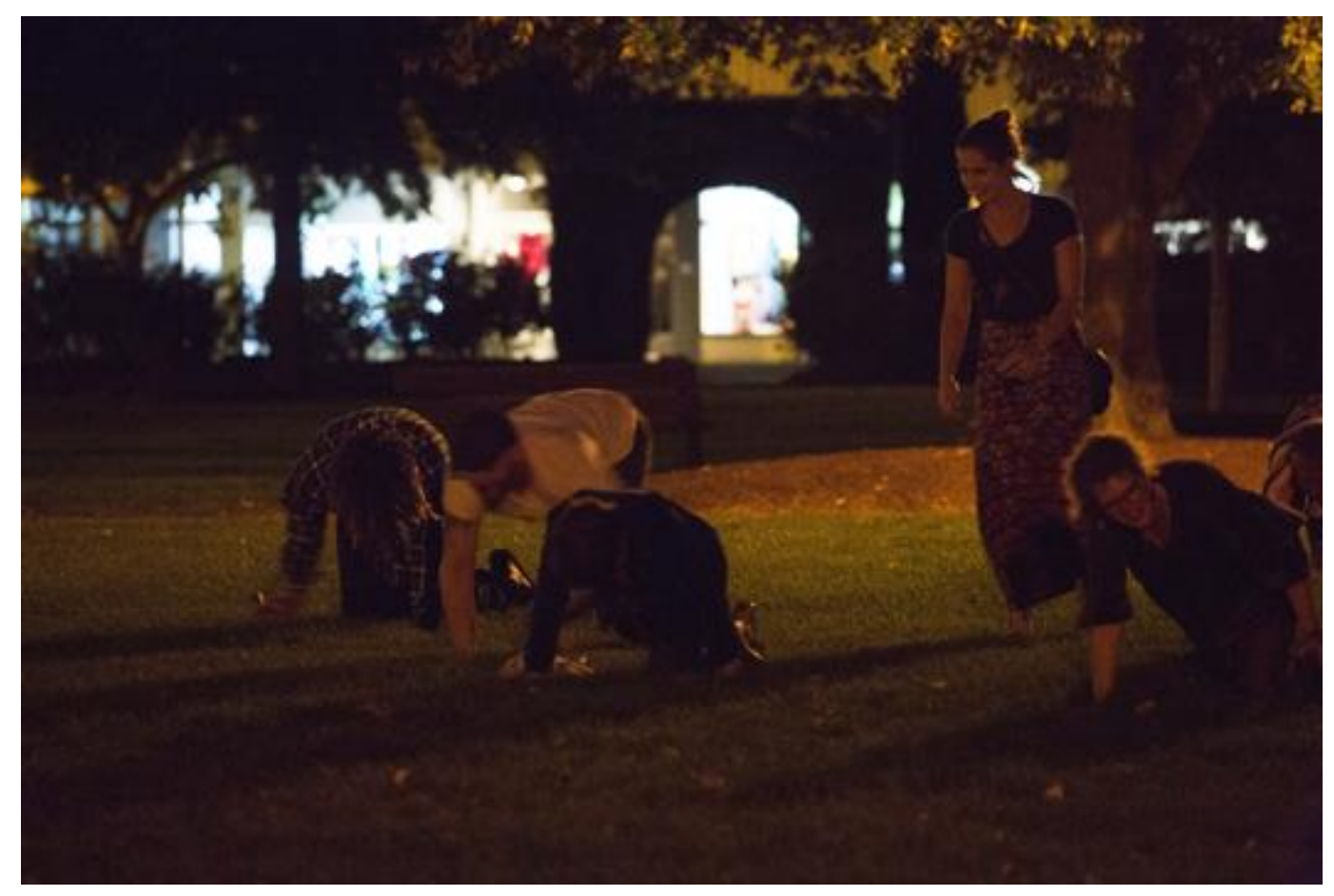

Crawling, Photo by Leonie Van Eyk, Castlemaine, 2016.

Towards the close of the tour, participants gathered on the blankets provided and lay down on the grass. Ms Guide invited the group to look up at the stars and played a dreamy aural soundscape, similar to a harp being played underwater, by local musician and sound artist Ros Bandt. At this point, Ms Guide acknowledged the fact that she had missed out on the previous 60,000 years of Indigenous history of the area. For about ten minutes we stared up into the expanse of night sky. I was hopeful that participants took in the information that the tour was only a partial and incomplete experience of Castlemaine. I wanted to bring attention to the gaping hole in Australia's historical story and highlight the absence of Indigenous knowledge content on the tour. I was also indicating that there was much about the history of the place that I didn't know, and as a white woman, never would. 
Material for the tour relied on "hybrid tactics" and the creation of "fictional and scientific knowledges" projected through story and activity. A mythogeographic method was developed for the duration of the tour, and each spectator-participant related to it differently. As a final task, Ms Guide invited the reclining group to imagine the past, present, and future in this moment, then posed the question: "are we in the place, or is the place in us?" This question concluded the physical tour, but it also becomes an ongoing question. Lingering in the liminal stage, where the boundaries of place, space, and body intersect, raises possibilities for new experiences and encounters. The tour explored what can and can't be done in public spaces and was an interpretation of easily available local information. It encouraged participants to see through different eyes and let go of preconceived ideas of performer/audience relations. The moving body was given an opportunity, through the performative event, to hold hands with strangers, trolley ride through a car park, and crawl on grass, therefore opening up the potential of place and how we may move through it differently. I wasn't able to create a complete historical account of Castlemaine, but that was never the point. I worked with what was at hand, what I could find out, and turned it into a journey layered with laughter that revealed new insights for both the group and the individual. The participants rested thoughtfully for the duration of the music and then filled out the questionnaire under flickering streetlights. Ms Guide then individually thanked them for being part of the event, and all stood around talking before the group dispersed into the night.

\section{Reflections}

Through active spectator participation in the performativity of Promenade Locale, physical imagining, movement, and sound precipitated an embodiment of place. A psychogeographic experience was potentially created through and with the performance. ${ }^{47}$ The participatory art of the Promenade Locale series followed one of the three ongoing functions which Claire Bishop sets out. She references:

The desire to create an active subject, one who will be empowered by the experience of physical or symbolic participation. The hope is that the newly emancipated subjects of participation will find themselves able to determine their own social and political reality. An aesthetic of participation therefore derives legitimacy from a (desired) causal relationship between the experience of a work of art and individual/collective agency. ${ }^{48}$ 
A quote from a participant, keen to offer their feedback a full six months after the performance of Promenade Locale \#3 in September 2016, is replicated below. I think it highlights Bishop's concept of the function of participatory performance. The remembered embodiment (referred to below as "acting things out") of both the physical and symbolic caused an altered relationship with the participant's reality.

I was reflecting after I went on the walk, and I was thinking about it afterwards, I think what was really interesting is that a lot of the things that we were doing that were just sort of silly and fun at the time, like the shopping trolleys and we pretended to be horses and galloped through the car park. But that really, that stuff really sticks, the physical movement, it kind of sticks in your mind, so for me, now when I go to the IGA car park I associate that with the fact that it was a horse stable in a way that was really...yeah once it's in your body, it's much more in your mind. The galloping and looking out over the creek flats too, imagining the races, that was pretty strong. I mean the whole thing, that whole walk and the visualizing from where we started, that underground tunnel. Yeah, it's quite, I mean certain things really stick in my mind and I think those were the things when we were acting a lot of things out.

At times, I sensed when the group became totally immersed in the activities of the tour. These moments were also reinforced for me when viewing post-performance photo and video footage. These instances seemed most efficacious when we undertook some sort of non-habitual physicality. Participants dropped their inhibitions when involved in physical activity, experiencing something more vividly once the words had been said and movement had become the priority.

\section{Conclusion}

In Promenade Locale the activity of walking is the link to the active spectator. Spectating is an activity, which in this work is framed as participation. It is here that Fischer-Lichte's "transformative aesthetics" 49 became alive through and with people's bodies. Activity is linked to the senses when requests are directed to the body to, for example, close one's eyes, gallop, or carry a heavy rock. This embodiment - through a dynamic physicality that involves exertion and calm, running and listening - has the potential to engage participants on a deeper level and affect the way they encounter and interact with place. Fischer-Lichte further defines the active role of the spectator:

... as the capacity to perceive attentively and involve all the senses; it relies on the willingness to undergo highly diverse, even disturbing and destabilizing experiences and corresponding transformations - at times requiring the 
relinquishment of focused attention in order to get lost in a kind of reverie - to engage in the process of what is happening and still not lose the faculty to reflect on what one has perceived, experienced and done, even if the latter may emerge clearly only after the performance has ended. ${ }^{50}$

The outcome of my experience of being Ms Guide was read through witnessing the real-time event and analyzing questionnaire responses. People's willingness to meet the unknown challenged concepts of everyday interactions and interpretations of performance and place. The tour enriched an experience of one's everyday place, through the people who participated in and responded to the "demonstratives" on offer. Aside from the immediate written feedback and the responses, I cannot really know what lasting effects participants took away from the tour. It was "in the moment" or "reverie" that I was aware of shifts in individual and group perception. The process of coming together as a group through the tour had a key influence on the experience and outcomes of each Promenade Locale event. In a group, participants were more likely to be provoked and empowered by each other's actions in a positive way. No one did interrupt to take the tour on a tangent, although I remained open and hopeful that they would. I understand the long-seeded convention of audience/performer relations, and Castlemaine locals may not have been confident in taking up the reins of a small and intimate live performance. In a regional town, especially at night the streets are very quiet and this kind of walking tour/performance was a new genre of art into the area. Some may have felt they didn't know enough about the town to offer up directions, some may have simply been too shy. However, a different audience possibly from Melbourne or one more versed in breaking with theatrical binaries may have taken up the challenge. I developed and believed in a relationship of mutual trust and openness with participants that valued their experience and involvement with the work.

After analyzing the feedback from the spectator-participants, I concluded that the score functioned successfully as a mythogeographic tour. It aimed, "to hypersensitize them to the fine textures, the conflicting and multiple narratives and the accidental ironies of these places; and to provoke them to make their own interrogations of them." ${ }^{51}$ We made and explored a new unique place through performance inside an existing one (Castlemaine), and that became an opportunity for different encounters between performer and audience. Both audience and performer became active spectator-participants in place, through the practice of the tour. 
Promenade Locale created a "brazen youthfulness" and carnivalesque experience that was "subject only to its laws, that is, the laws of its own freedoms." The mythogeographic framework of the "mis-guided" tour, noted throughout the article, became an example of Phillip's "unruly mix" of people and place. The active experiences, full of potential through sensing and motion, challenge what we take for granted in the everyday. De Certeau's "definition of walking as a space of enunciation" extended to include the activities of galloping, scurrying and crawling through the streets, marking out vocalizations of place through the body. One participant wrote, "I feel to be more accepting and tolerant of our diverse human nature and culture." 53 This fleeting thought written shortly after the event expands on the possibilities of the walking performance and reaches beyond the initial intention of the work. I would go so far as to make the claim that the possibility of imagining changing relationships between performer, spectator and place can be discovered through the performance of Promenade Locale.

${ }^{1}$ Michel de Certeau, The Practice of Everyday Life, trans. Steven Rendall (Berkeley: University of California Press, 2011), 117.

${ }^{2}$ For example, see Deirdre Heddon and Cathy Turner, "Walking Women: Shifting the Tales and Scales of Mobility," Contemporary Theatre Review 22, no. 2 (2012): 224-36.

${ }^{3}$ For example, see Mike Pearson, "Performance: Bubbling Tom," in In Comes I (Exeter: University of Exeter Press, 2006), 21-31.

${ }^{4}$ Crab Man \& Signpost, A Sardine Street Box of Tricks (Axminster: Triarchy Press, 2012), 38.

${ }^{5}$ Wrights \& Sites, “About," http://www.mis-guide.com/ws/about.html. Accessed February 1, 2018.

${ }^{6}$ Perdita Phillips, "Walk 'Til You Run out of Water," Performance Research 17, no. 2 (2012): 104-06.

${ }^{7}$ Mark Minchinton and Domenico de Clario, "Kellerberrin on Our Minds," About Performance, no. 7 (2007): 45-67.

${ }^{8}$ Domenico de Clario, "Walking Slowly Downhill," http://domenicodeclario.com/walking-slowly-downhill/, Accessed February 1, 2018.

${ }^{9}$ Fiona Wilkie, "Site-Specific Performance and the Mobility Turn," Contemporary Theatre Review 22, no. 2 (2012): 209-210. Wilkie writes particularly about the work of Melbourne based artist and academic Mick Douglas in her critique of mobility vs. walking practices.

${ }^{10}$ Environmental Performance Authority, "Smellbourne Toliet Tour," http://epaperformance.org/event/smellbourne-toilet-tour-3/. Accessed February 1, 2017. 
${ }^{11}$ Performing Mobilites, "Passages: Mobile Performances," http://www.performingmobilities.net/symposium/passages/. Accessed July 24, 2017.

12 Punctum, "Ramble by Mish Grigor," http://www.punctum.com.au/residencies/seedpod-amplified/ramble. Accessed February 1, 2017.

${ }^{13}$ Punctum, "Expanding Movement Fields by Kaya Barry," http://www.punctum.com.au/residencies/seedpod/expanding-movement-fields. Accessed February 1, 2017.

${ }^{14}$ Punctum, "Big Walk to Golden Mountain," http://www.punctum.com.au/works/big-walk-golden-mountain-2017. Accessed February 1, 2018.

${ }^{15}$ de Certeau, The Practice of Everyday Life, 98.

${ }^{16}$ Wrights \& Sites. "Mis-guiding the City Walker," http://www.mis-guide.com/ws/documents/citywalker.html. Accessed February 1, 2108.

${ }^{17}$ Erika Fischer-Lichte, "The Art of Spectatorship," Journal of Contemporary Drama in English 4, no. 1 (2016): 170.

${ }^{18}$ de Certeau, The Practice of Everyday Life, 91-93.

${ }^{19}$ Fischer-Lichte, "The Art of Spectatorship," 176.

${ }^{20}$ Phil Smith, "Turning Tourists into Performers: Revaluing Agency, Action and Space in Sites of Heritage Tourism," Performance Research 18, no. 2 (2013): 112.

${ }^{21}$ Barbara Bolt, “Artistic Research: A Performance Paradigm?” Parse Journal Repetitions and Reneges, no. 3 (2016): 134.

22 The book provides tactics and strategies for the "mis-guided" tour, see Crab Man and Signpost, A Sardine Street Box of Tricks, Axminster: Triarchy Press, 2012.

${ }^{23}$ Phil Smith, "Psychogeography Now," in Psychogeography Symposium - Taking it to the Streets: Empowering Interactions with the Urban Environment (Edge Hill University, Plymouth: Academia.com, 2016), 3. See also, Tina Richardson, ed. Walking Inside Out, Contemporary British Psychogeography (London, New York: Rowman \& Littlefield, 2015).

24 The project was partly funded by the local Mount Alexander Shire Council, which assisted in my decision to make it a free event. I had acquired ethics approval from Federation University Australia and assessed any potential risks beforehand.

${ }^{25}$ Guy Debord, “Theory of the Dérive," in Internationale Situationiste\#2 (1958): 1.

${ }^{26}$ Edward S. Casey, "Between Geography and Philosophy: What Does It Mean to Be in the Place-World?," Annals of the Association of American Geographers 91, no. 4 (2001): 687.

${ }^{27}$ de Certeau, The Practice of Everyday Life, 99.

${ }^{28}$ Pearson, Site-Specific Performance, 109.

${ }^{29}$ Ibid.

${ }^{30}$ Fischer-Lichte, "The Art of Spectatorship," 171.

${ }^{31}$ Smith, "Turning Tourists into Performers," 112.

32 de Certeau, The Practice of Everyday Life, 110.

${ }^{33}$ Participant feedback, Promenade Locale \#3, March 2016.

${ }^{34}$ Phil Smith, On Walking (Axminster: Triarchy Press, 2014), 59.

${ }^{35}$ I had literally embodied the concept of the "mis-guided" tour guide, to become "Ms Guide" for the event. 
${ }^{36}$ Smith, "Turning Tourists into Performers," 106-07.

${ }^{37}$ Fischer-Lichte, "The Art of Spectatorship," 169.

${ }^{38}$ The spoken text, "It was said that 'back in the day' a tunnel used to run under the ground from the pub to the hotel about 100 meters up the road. Men would arrive at the pub, apparently for an innocent pint, but would instead 'scurry' through the tunnel in the dark, to visit the working ladies at the hotel. They would then make it back to the pub in time for their wives to think they were still drinking beer."

${ }^{39}$ Participant feedback, Promenade Locale \#3, March 2016.

${ }^{40}$ Fischer-Lichte, "The Art of Spectatorship," 169.

${ }^{41}$ Participant feedback, Promenade Locale \#2, March 2015.

${ }^{42}$ Mandy Jean and David Moloney, "Forest Street to Forest Creek Heritage Assesment," (Mount Alexander Shire Council, 2015).

${ }^{43}$ de Certeau, The Practice of Everyday Life, 108.

${ }^{44}$ Fischer-Lichte, "The Art of Spectatorship," 173.

45 "A Town Walk in Historical Castlemaine," ed. Castlemaine Historical Society Inc. (Castlemaine Visitor Information Centre, 2014 ).

${ }^{46}$ Participant feedback, Promenade Locale \#3, March 2016.

${ }^{47}$ Smith, "Psychogeography Now," 4.

${ }^{48}$ Claire Bishop, "Introduction," in Participation, ed. Claire Bishop (London : Cambridge, Mass.: Whitechapel MIT Press, 2006), 12.

${ }^{49}$ Fischer-Lichte, "The Art of Spectatorship," 176.

${ }^{50}$ Ibid., 178.

${ }^{51}$ Smith, "Turning Tourists into Performers," 103.

${ }^{52}$ M. M. Bakhtin, Rabelais and His World (Bloomington, Ind.: Indiana University Press, 1984), 7.

${ }^{53}$ Participant feedback, Promenade Locale \#2, March 2015. 